\title{
РЕГУЛЮВАННЯ ХОЛОДОПРОДУКТИВНОСТІ БАГАТОКОМПРЕСОРНОЇ ХОЛОДИЛЬНОЇ УСТАНОВКИ НА ОСНОВІ АЛГОРИТМІВ НЕЧІТКӦ̈ ЛОГІКИ
}

\author{
Грітчін А.B. ${ }^{1}$ \\ ${ }^{1}$ Одеська національна академія харчових технологій, Одеса
}

Copyright (C 2014 by author and the journal "Automation technological and business - processes". This work is licensed under the Creative Commons Attribution International License (CC BY). http://creativecommons.org/licenses/by/4.0/

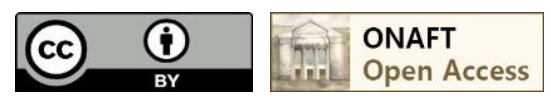

DOI: $10.15673 / 2312-3125$.

\begin{abstract}
Анотація
В даній статті розглядається принцип побудови алгоритму регулювання холодопродуктивністю багатокомпресорної холодильної установки на теорії нечітких множин і нечіткої логіки. В останні роки в системи автоматизації технологічних процесів почали активно впроваджуватися моделі, методи та технічні засоби, основані на теорії нечітких множин. Поняття нечіткої множини - це спроба математичної формалізації нечіткої інформації для побудови математичної моделі. В основі цього поняття лежить уявлення про те, що елементи що складають дану множину, мають спільні властивості, можуть мати ці властивості в різній степені, а отже і належать даній множині 3 різною степеню. При такому підході висловлення типу «цей елемент належить даній множині» втрачає сенс, оскільки необхідно вказати «як сильно» чи в якому степені елемент задовольняс властивостям даної множини. Якщо подивитись на результати моделювання, характеристики системи поліпшились. Підвищується стійкість системи до стрибкоподібних збурень, а також до високочастотних збурень. Завдяки впровадженню в систему регулятора на нечіткій логіці, існус можливість під час експлуатації змінювати вагу правил та проводити допоміжні правила, що можуть бути пов'язані 3 іншими параметрами холодильного циклу (кипіння, конденсації, рівня холодоагентів в теплообмінних апаратах), та правила, що можуть бути пов'язані 3 експлуатаційними особливостями (тип роботи в залежності від часу доби, чи пори року, енергозберігаючий режим, тощо), допоміжні реакції на деякі події. Переважна більшість сучасних холодильних машин оснащена однокомпресорними агрегатами 3 позиційною системою керування. Це пов'язано 3 відносною простотою їх конструювання, монтування, а також 3 меншою вартістю агрегату та його системи автоматизації по відношенню до багатокомпресорних.
\end{abstract}

\section{Abstract}

In this article the principle of algorithm development regulation cooling capacity of the refrigeration unit with multiple compressors on the theory of fuzzy sets and fuzzy logic. In recent years, process automation systems were developed models, methods and hardware based on the theory of fuzzy sets. The concept of fuzzy set - an attempt to mathematical formalization of fuzzy information to build mathematical models. At the heart of this concept is the notion that the elements that make up this set, have common properties, these properties can have a different degree, and therefore are given multiple different degree. In this approach, statements like "this element belongs to a given set of" meaningless, because you need to specify "how much" or in any degree element satisfies the properties of the set. Looking at the results of simulation, system characteristics improved. Growing stability of the 
system to intermittent disturbances, as well as high-frequency disturbances. Through the introduction of a system controller on fuzzy logic, it is possible during operation to change the weight of rules and conduct ancillary rules that may be associated with other parameters refrigeration cycle (boiling, condensation of refrigerants in heat exchangers), and rules can be related to the operating characteristics (type of work, depending on the time of day, or season, power-saving mode, etc.), auxiliary reactions to certain events. The majority of modern refrigeration units equipped one compressor units with position control system. This is due to the relative simplicity of their design, mounting, and with lower cost unit and its automation systems in relation to refrigeration unit with multiple compressors.

Ключові слова

Нечіткий регулятор, алгоритм Сугено, АСР багатокомпресорної холодильної установки.

Вступ

Дослідження, про які піде річ в статті, відносяться до області енергозберігаючих технологій і обладнання. На сьогоднішній день економія енергоресурсів і підвищення ефективності виробництва є одним із найпріоритетніших напрямків розвитку. Вирішенню цієї проблеми в значній мірі допомагає підвищення якості регулювання технологічних процесів в реальних умовах експлуатації.

Регулювання холодопродуктивністю багатокомпресорні холодильної установки характеризуються значними зв'язками між окремими елементами, великою кількістю зовнішніх і внутрішніх впливів, частина 3 яких недоступна для контролю, і високими вимогами до величини припустимих відхилень регулюючих параметрів від заданих значень цих параметрів. Значна частина відмов роботи технологічного обладнання пов'язана 3 приладами контролю, системами захисту і регулювання.

На сьогоднішній день статистика показує, що існує значна частина відмов, поломок автоматичних систем регулювання (АСР), і пов'язано це 3 погіршенням якості регулювання через зміну параметрів у системі. Тому доцільно застосовувати нові підходи при проектуванні АСР. Одним з найефективніших засобів підвищення стійкості роботи та якості регулювання автоматичних систем є використання регуляторів на базі нечіткої логіки.

Створення нечіткої системи для регулювання холодопродуктивності багатокомпресорної холодильної установки

Створення нечіткої системи регулювання складається з ряду етапів:

1. Вибір бажаної характеристики перехідного процесу. Як приклад прийнята траєкторія АCP із ПІ регулятором й об'єктом першого порядку із запізнюванням. Налаштунки регулятора оптимізовані за інтегральним квадратичним критерієм помилки регулювання. Також слід відмітити, що із-за несиметричності динаміки зміни температури в холодильній камері(пониження температури під чар роботи компресора швидше аніж підвищення під час його зупинки) слід обмежити пере регулювання;

2. Побудова нечіткого алгоритму керування на базі алгоритму Сугено. В системі даного типу база знань будується $з$ правил, які мають вигляд "Якщзо $x_{1}=$ низкий и $x_{2}=$ середний, то $y=a_{0}+a_{1} x_{1}+a_{2} x_{2}$ ";

3. Нечіткий висновок по алгоритму Такаги-Сугено виконується по нечіткій базі знань:

$$
\bigcup_{p=1}^{k_{j}}\left(\bigcap_{i=1}^{n} x_{j}=a_{i, j p} \text { з вагою } w_{j p}\right) \rightarrow y=b_{j, 0}+b_{j, \mathbf{1}} \cdot x_{1}+b_{j, \mathbf{z}} \cdot x_{\mathbf{z}}+\cdots+b_{j, n} \cdot x_{n} .
$$

Правила у системі Сугено задаються лінійною функцією від входів:

$$
d_{j}=b_{j, 0}+\sum_{i=1, n} b_{j, i} \cdot x_{i}
$$

Таким чином правила в базі Сугено являються свого роду перемикачами з одного лінійного закону «вихідвхід» на інший, теж лінійний. Границі областей розмиті, отже одночасно можуть виконуватись декілька законів, але з різними степенями.

4. Дефазифікація проводиться за методом зваженого середнього(центру ваги). 


\section{ㄱ СТУДЕНТСЬКА НАУКА}

Використання алгоритмів керування з нечіткою логікою зумовлено особливістю розглянутої схеми і зокрема, розкладанню безперервного керуючого сигналу на вектор 3 трьох елементів: двох дискретних (на опорні компресори) і один безперервний (на компресор з неперервним регулюванням холодопродуктивності):

$$
\begin{aligned}
& U_{y}^{e}=U_{K 1}^{\odot}+U_{K z}^{d}+U_{K a}^{d} \\
& \text { де } U_{K 1}^{\mathbb{e}}=U y^{\mathbb{e}}-U_{K 2}^{d}-U_{K a}^{d} \text {, } \\
& U_{K \mathbf{I}}^{d}=\left\{\begin{array}{l}
1, \text { пи } U_{y}^{e}>1 \\
0, \text { при } U_{y}^{e}<1
\end{array} U_{K a}^{d}=\left\{\begin{array}{l}
1, п р и U_{y}^{e}>2 \\
0, \text { при } U_{y}^{e}<2
\end{array}\right.\right.
\end{aligned}
$$

Виходячи $з$ цього система повинна мати підвищену стійкість і зменшене перерегулювання для уникнення зайвих пусків опорних компресорів, при збереженні необхідної швидкості. Тобто необхідна система управління, яка в залежності від помилки регулювання буде використовувати різні закони регулювання і при цьому при переході від одного закону до іншого не повинно бути стрибкоподібних впливів, які негативно впливають на вихідний сигнал. Побудувати таку систему можна за допомогою алгоритмів нечіткої логіки.

На першому етапі ми обрали лінгвістичну змінну для відхилення температури в холодильній камері від заданої з такими параметрами:

- назва: «dT»

- універсальна множина U[-45;10], на якій буде відбуватись стеження за відхиленням температури від заданої

- $\quad$ терм-множина T, яка складається з таких термів $\{\mathrm{BN}, \mathrm{LN}, \mathrm{NZ}, \mathrm{Null}\}$, які зображені на рисунку 1 . Терм BN - трапецієвидна функція приналежності, яка відповідає приналежності сигналу до дуже великих відхилень, які мають місце лише при пуску системи, чи довгому простої, тому в правилах приналежність цьому терму виводить систему на максимальну потужність. трикутний терм LN -середнє негативне відхилення, трикутний терм NZ - мале відхилення, Null - відхилення біля нуля чи додатнє.

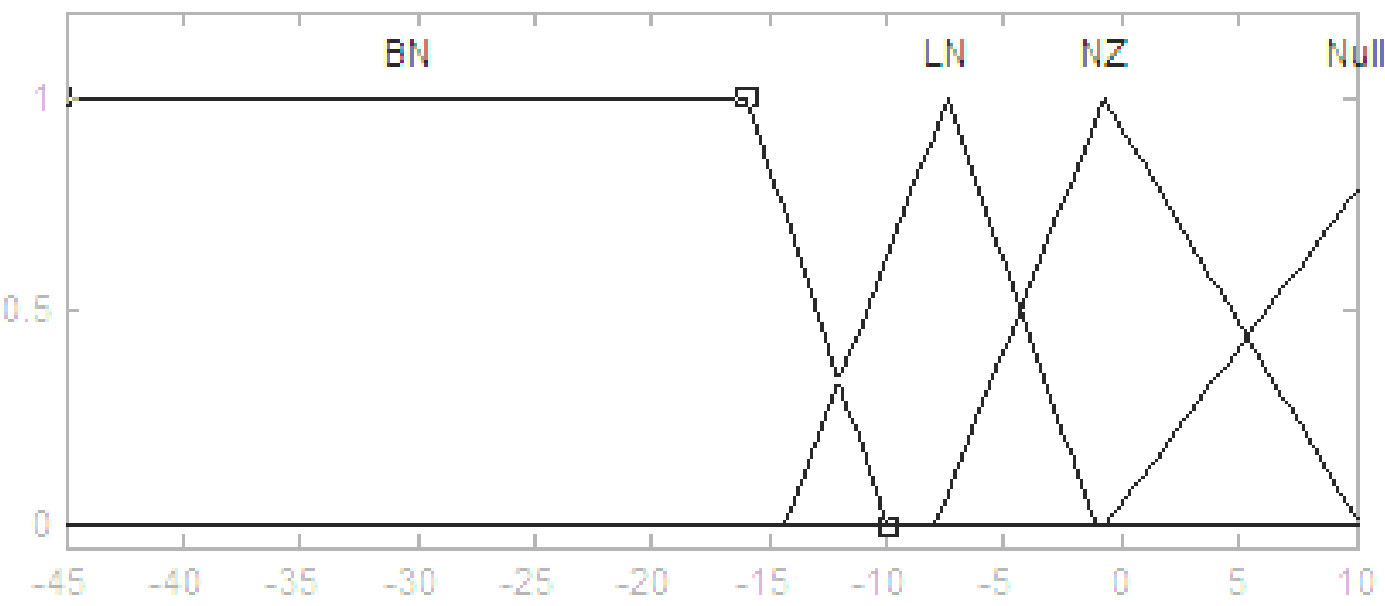

Рис. 1 - Функції приналежності до нечітких множин

Для опису вихідний лінгвістичної змінної задалися системою типу Сугено. У системах типу Сугено база знань складається 3 правил виду "Якщо $x_{1}=$ низкий и $x_{2}=$ средний, то $y=a_{0}+a_{1} x_{1}+a_{2} x_{2}$ ". Коефіцієнти при змінних задаються у вигляді вектора $з$ кількістю елементів, яка дорівнює кількості входів+1. Тобто у вигляді: [коефіцієнт для 1го входу, коефіцієнт для 2го входу, ..., коефіцієнт для го входу, вільний коефіцієнт] У вихідний змінної описані такі терми:

- Min-мінімальний вихідний сигнал (0), з вектором [0; 0; 0;0];

- Мах - максимальний вихідний сигнал (1), з вектором $[0 ; 0 ; 0 ; 1]$;

- High - сигнал від регулятора з високою швидкодією (П-регулятор), 3 вектором [0; 0; $1 ; 0]$;

- $\quad$ Low - сигнал від регулятора $з$ підвищеною стійкістю та точністю регулювання (ПІ-регулятор), 3 вектором $[0 ; 1 ; 0 ; 0]$. 
Вирішено використовувати сигнали на вході від класичних(П- та ПІ-) регуляторів для наочності роботи схеми, та полегшення етапу знаходження оптимальних коефіцієнтів. В кінцевому варіанті АСР всю генерацію керуючого сигналу буде реалізовано в блоці нечіткого регулятора.

Для сигналів з блоків П та ПІ регуляторів в систему введено ще дві вхідних змінних: P-reg та PI-reg відповідно.

Правила істинності для даної структури мають вигляд :

Якщо $\mathrm{dT}=\mathrm{BN}$ то output $\sim$ Max 3 вагою 1 ; Якщо $\mathrm{dT}=\mathrm{LN}$ то output $\sim$ High 3 вагою 1 ; Якщо dT $=\mathrm{NZ}$ то output1 $\sim$ Low 3 вагою 1; Якщо dT $=$ BN то output $1 \sim$ Null $з$ вагою 0,5.

Після моделювання отримали графіки перехідних процесів, зображені на рисунку 2.

На рисунку позначені:

$\mathrm{T}_{\mathrm{X \kappa}}$ - температура в холодильній камері; $\mathrm{T}_{\mathrm{OC}}$ - температурне навантаження; $\mathrm{U}_{\Sigma}$ - сумарний керуючий сигнал на виході Fuzzy-регулятора; $\mathrm{U}_{\mathrm{K} 1}-$ керуючий сигнал для першого компресора(неперервний); $\mathrm{U}_{\mathrm{K} 2}-$ керуючий сигнал для другого компресора(дискретний); $\mathrm{U}_{\mathrm{K} 3}$ - керуючий сигнал для третього компресора(дискретний).

Із результатів моделювання виявилося, що характеристики системи поліпшились. Підвищилась стійкість системи до стрибкоподібних збурень по температурі навколишнього середовища, а також до високочастотних збурень. Кількість включень компресорів з дискретним керуванням знизилась до чотирьох за 2000 одиниць часу, які відповідають щонайменше 1.5 добам. Це у 240 разів менше ніж при дискретному керуванні та у 8 разів менше ніж при керуванні за допомогою класичного ПІ-регулятора.

Завдяки впровадженню в систему регулятора на нечіткій логіці, існує можливість під час експлуатації змінювати вагу правил та проводити допоміжні правила, що можуть бути пов'язані 3 іншими параметрами холодильного циклу (кипіння, конденсації, рівня холодоагентів в теплообмінних апаратах), та правила, що можуть бути пов'язані $з$ експлуатаційними особливостями (тип роботи в залежності від часу доби, чи пори року, енергозберігаючий режим, тощо), допоміжні реакції на деякі події.

Висновки: Таким чином, регулювання холодопродуктивністю багатокомпресороної холодильної установки на теорії нечітких множин и нечіткої логіки забезпечує:

- $\quad$ при зміні параметрів об'єкта в 3 рази кращі показники якості (в порівнянні з класичним ПІ-регулятором): менше значення перерегулювання (на $32 \%$ ) та часу регулювання (на $185 \mathrm{c}$ );

- вибір оптимального режиму роботи;

- зміну температури та підтримання заданої;

- зменшення витрат електроенергії на 20-40\%.

Література

1. Заде Л. Понятие лингвистической переменной и его применение для принятия приближённых решений. М.: Мир, 1976. 165 с.;

2. Беллман Р., Заде Л. Принятие решений в расплывчатых условиях // Вопросы анализа и процедуры принятия решений: Сб. статей / Пер. с англ.; Под ред. И.Ф.Шахнова. М., 1976. С.172-215;

3. Обработка нечеткой информации в системах принятия решений / А.Н.Борисов, А.В.Алексеев;

4. .В. Меркурьева и др. М.: Радио и связь, 1989. 305 с.;

5. Кофман А. Введение в теорию нечетких множеств. М.: Радио и связь, 1982. 432 с.

\section{References}

1. Zade L. Ponyatye lynhvystycheskoy peremennoy i eho prymenenye dlya prynyatyya pryblyzhenyh resheniy. M.: Myr, 1976. 165 s.;

2. Bellman R., Zade L. Prynyatye resheniy v rasplyvchatyh uslovyah // Voprosy analiza i protseduri prynyatiya resheniy: Sb. statey / Per. s anhl.; Pod red. Y.F.Shakhnova. M., 1976. S.172-215.;

3. Obrabotka nechetkoy informatsii v systemah prynyatiya resheniiy / A.N.Borysov, A.V. Alekseev;

4. H.V. Merkur'eva i dr. M.: Radio i svyaz', 1989. 305 s.;

5. Kofman A. Vvedenie v teoriyu nechetkyh mnozhestv. M.: Radio y svyaz', 1982. $432 \mathrm{s.}$

Науковий керівник: Гончаренко О.Є., доц.., к.т.н. кафедри АВП ОНАХТ 